\section{Medicine Updates}

Faculty of medicine

January 2021,volume 4, issue 4 https://muj.journals.ekb.eg dean@med.psu.edu.eg vice_dean_postgraduate@med.psu.edu.eg

DOI: 10.21608/muj.2020.55594.1037

ISSN : 2682-2741

Submitted: $28 / 12 / 2020$

Accepted : 29/12/2020

Pages:120- 137

\title{
" Proposal of the therapeutic nutrition clinic TNC, project in Port-Said university hospital"
}

Dr.Nesma Adel Elgohary, Faculty of medicine Suez Canal University 2009, Assistant lecturer of histology \& genetics faculty of medicine port said university. (Corresponding author)

Dr. Ahmed Ibrahim ABDOU Ali Mazroua, Faculty of Medicine Banha University 1991..june,

MBBCH Post graduate high Diploma in internal medicine Zagazig university May 1996, Internal medicine specialist EI Zohour General hospital in port said (general health insurance).

Dr.Reem Tawfik Elsayed, faculty of pharmacy Assuit University 2005, manager of stores port said elsalam hospital

Dr. Shaimaa Elhamy Abdelrehem, Faculty of pharmacy Suez Canal University 2008, pharmacist at the main store of Elsalam portsaid hospital

Ms Sabreen Mohamed Saber Elsaid, Faculty of nursing 2006, Almansora University, Head nurse ICU Alhayat Port foad hospital

Dr. Nahed El sayed Ezzat, faculty of pharmacy Cairo University 1988, Chef of pharmacists El salam Port Said hospital

Dr. Heba tallah Heussin Ali Elgohary

Faculty of pharmacy Cairo University, 2008 Infection control team manager at al-Hayat PortFoad hospital

Dr. Heba Gomaa Aladham, faculty of pharmacy Misr International University 2006, pharmacist at the main store of Elsalam Port-Said hospital

\section{ABSTRACT}

\section{Background :}

- Therapeutic Nutrition is now one of the most updated and recent limes of management of many diseases of adult and childhood and decreasing the mortality and morbidity rates and even beneficial for the healthy peoples this means that therapeutic nutrition clinic is beneficial for the all society

- Therapeutic Nutrition, exercise and life style modifications are very important item of treatment called non pharmacological therapy 
- The therapeutic nutrition, obesity and thinness management center in portsaid university hospital will be very beneficial for diseased patients and healthy people in port-said and at the same time will accomplish financial profits at the present time and the future.

\section{Aim of the study :}

Providing therapeutic nutrition clinic TNC that will promote health in all members our society not only the diseased ones but also the healthy one. It will help them improve quality of life this will decrease morbidity \& mentality rates. This will increase persons producorial in our community.

\section{Methodology :}

SWOT analysis , TOWS study, Feasibility study, Budgeting of the project, Legal study , Environmental study, Political study , Social study , catastrophe plan, methods of cost reduction and establishment of : risk management plan, financing plan and development plan .

\section{Conclusion:}

- Providing therapeutic nutrition clinic TNC that will promote health in all members our society not only the diseased ones but also the healthy ones.

- It will help them improve quality of life this will decrease morbidity \& mentality rates.

- This will increase persons productivity in our community.

\section{Key words :}

- TNC; obesity and thinness, exercise, health of community, project .

\section{Introduction}

- Therapeutic Nutrition is now one of the most updated and recent limes of management of many diseases of adult and childhood and decreasing the mortality and morbidity rates and even beneficial for the healthy peoples this means that therapeutic nutrition clinic is beneficial for the all society

- Therapeutic Nutrition, exercise and life style modifications are very important item of treatment called non pharmacological therapy

- The therapeutic nutrition, obesity and thinness management center in portsaid university hospital will be very beneficial for diseased patients and healthy people in port-said and at the same time will accomplish financial profits at the present time and the future.

- This project for Therapeutic Nutrition center is Avery practical project and have the character of ongoing continuity in future.

- The center will have many clinics and other activities included in the process of non-pharmacological therapy e.g. Exercise gym.

- Swimming pool, hydrotherapy and Jacuzzi, physiotherapy clinics followed by physiotherapist specially and so on. 


\section{AIM OF THE PROJECT}

Providing therapeutic nutrition clinic TNC that will promote health in all members our society not only the diseased ones but also the healthy one. It will help them improve quality of life this will decrease morbidity $\&$ mentality rates. This will increase persons productivity in our community.

\section{Material \& Methods FEASIBILITY STUDY}

- Application SWOT, TOWS and ETOP on our project therapeutic nutrition obesity and thinness center in port- said university hospital.

- The best strategy is to transform threats $\stackrel{\text { to }}{\longrightarrow}$ opportunities and weakness

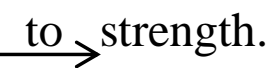

Ref. Demand Theory - ADAM HAYES Updated Jul 8, 2019

Ref. Feasibility Study - By Simplilearn - Aug 20, 2020

Ref. Feasibility Study - Kathy, March 27, 2019

\section{Brainstorming}

- We discuss with our colleagues of group in hospital management team and they give us these ideas about the project of therapeutic nutrition, obesity and thinness management clinic in port-said university hospital.

\section{Search the net for information.}

We searched in a lot of websites and journals online.

\section{Define the customer.}

Healthy peoples.

Diseased peoples (patients).

\section{Study the market.}

The market is so promising for the therapeutic nutrition clinical

\section{Define competitors.}

Private clinics and units for physic- therapy.

Private units for management of obesity and thinness.

Private clubs for health and physical fitness including athletes equipment, swimming pool, Jacuzzi and hydro - therapy.

\section{HR - Job descriptions, Job specifications \& Estimating Salaries}

HR (human resource manager and employee)

Will define the reasonable salaries of the employee and the qualification, skills needs to perform these jobs (job specification and job description) Ref. job description JAMES PHELAN MARCH 22, 2018 
The Building, Materials and the Machines -Estimating Cost, Maintenance of the Building \& Machines

- There must be specialized consultation companies for engineering, building, selling and buying lands.

- In our project we will need about $500 \mathrm{~m} 2$.

- Specialized company for performing the construction of the building from A TO Z and machines, the cost and the maintenance of the building.

Ref. A cost management - Liliana Neriz - November 2014

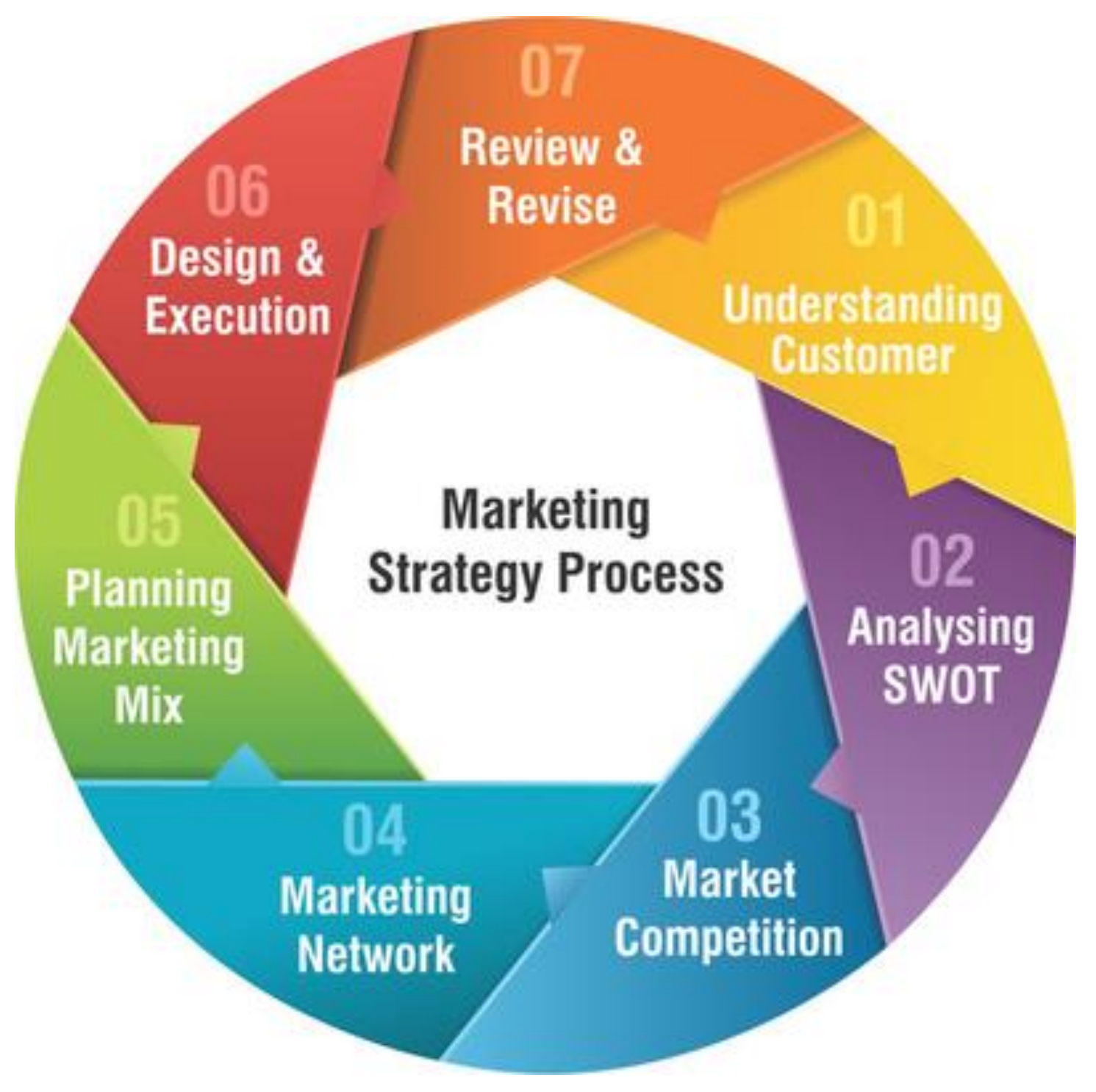

Ref. marketing - Michael Richter 


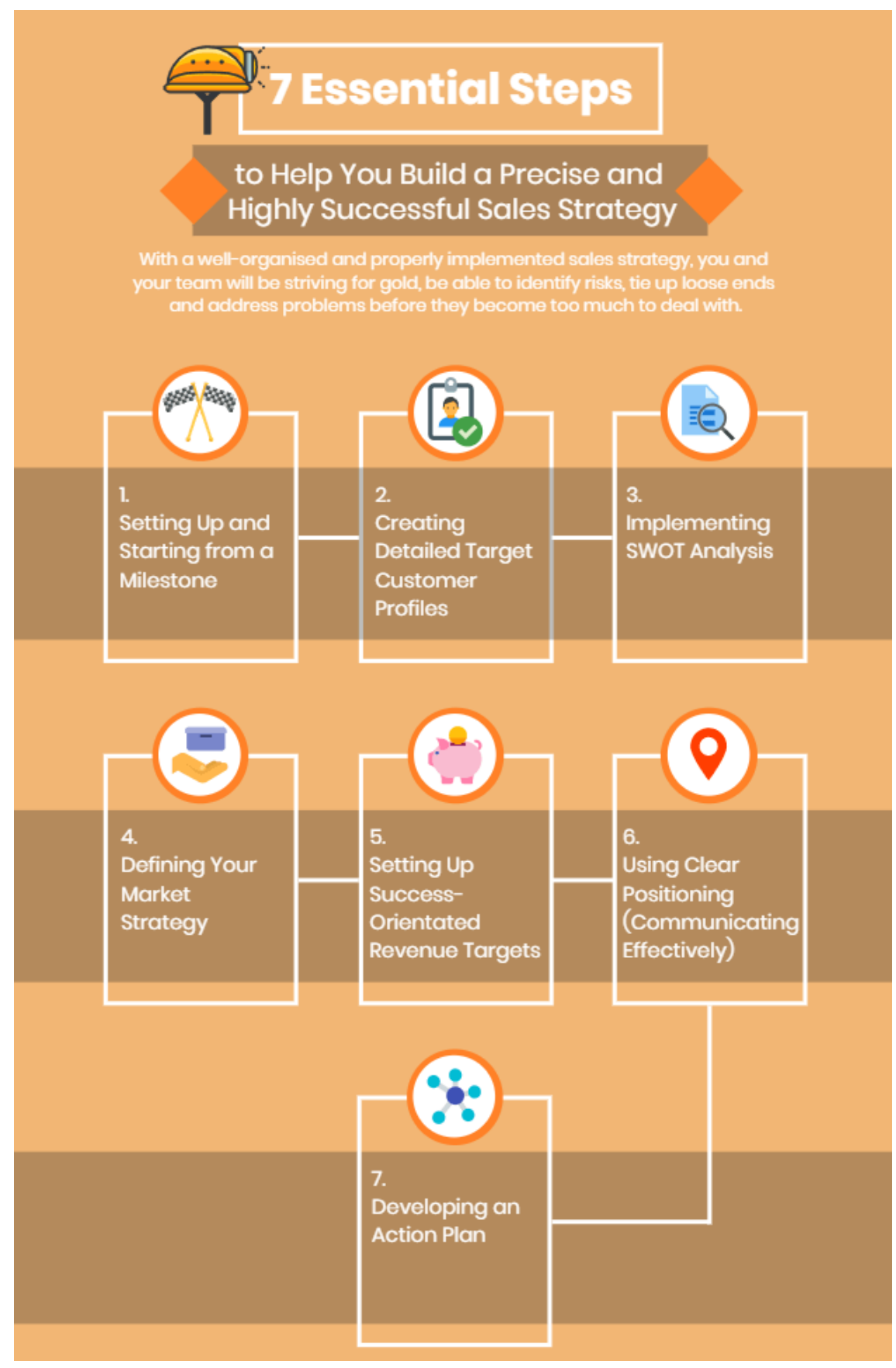

7essential steps for highly successful sales

Ref. sales and marketing - (C2014 Australian Business Consulting \& Solutions Ref. Market Segmentation - JENNIFER YESBECK

Ref. Marketing Strategy - By ADAM BARONE Reviewed By MARGARET JAMES

Updated Apr 29, 2020

Ref. Types of Marketing Strategies - Feb 20, 2014

Ref . The Sales Strategy Dave Egloff | March 12, 2019

\section{Methods of training}

- Class room learning

- Host your training on line

- All the medical and non-medical staff must be obliged for an advanced training 


\section{Methods of monitoring}

- Observation, Talking with people

- Monitoring work performance and output

- Employees surveys (before, during, and after the change)

- Financial recording, provide direct feedback

- Questionnaires

- Measuring the time it takes to complete tasks

- Recording questions asked

Ref. Monitoring techniques

Ref. DIETARY SERVICES

\section{Methods of Control}

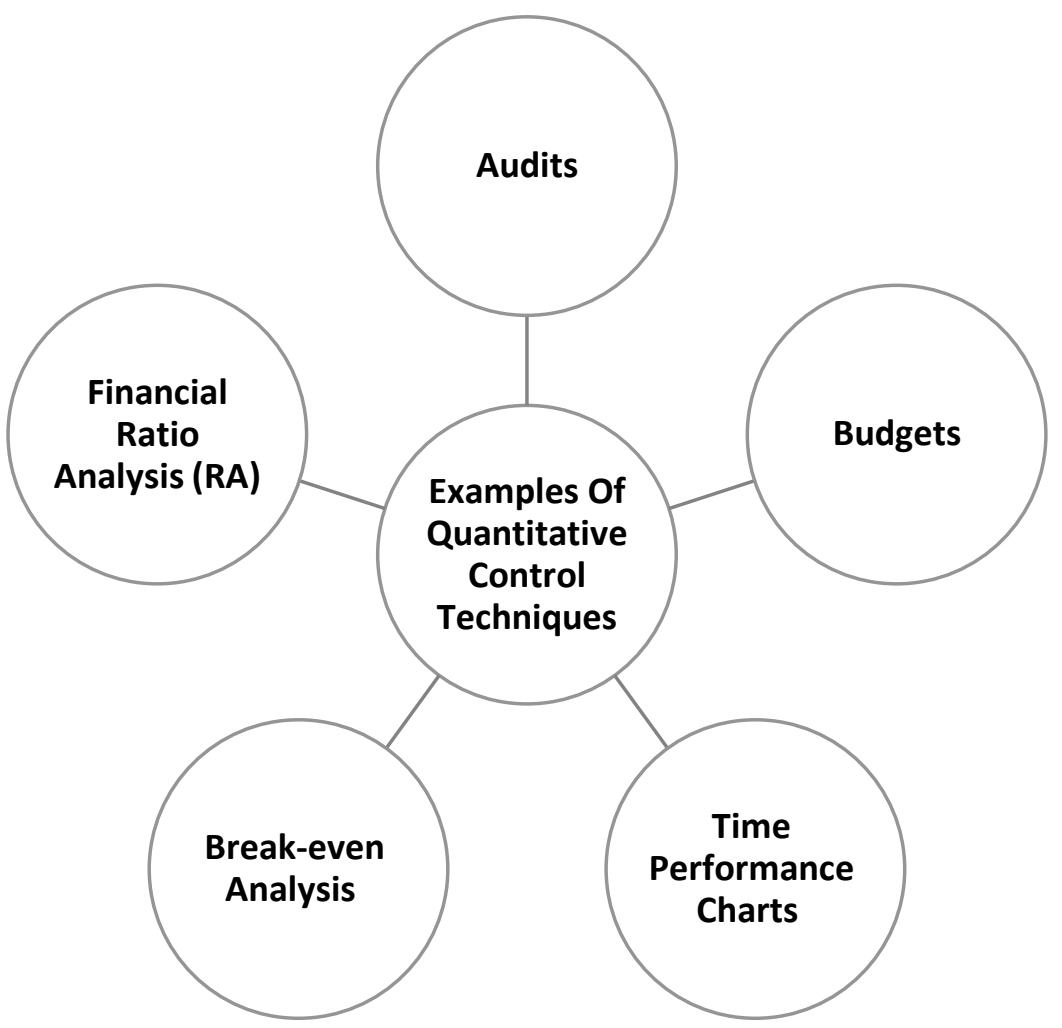

The Patient Circulation 


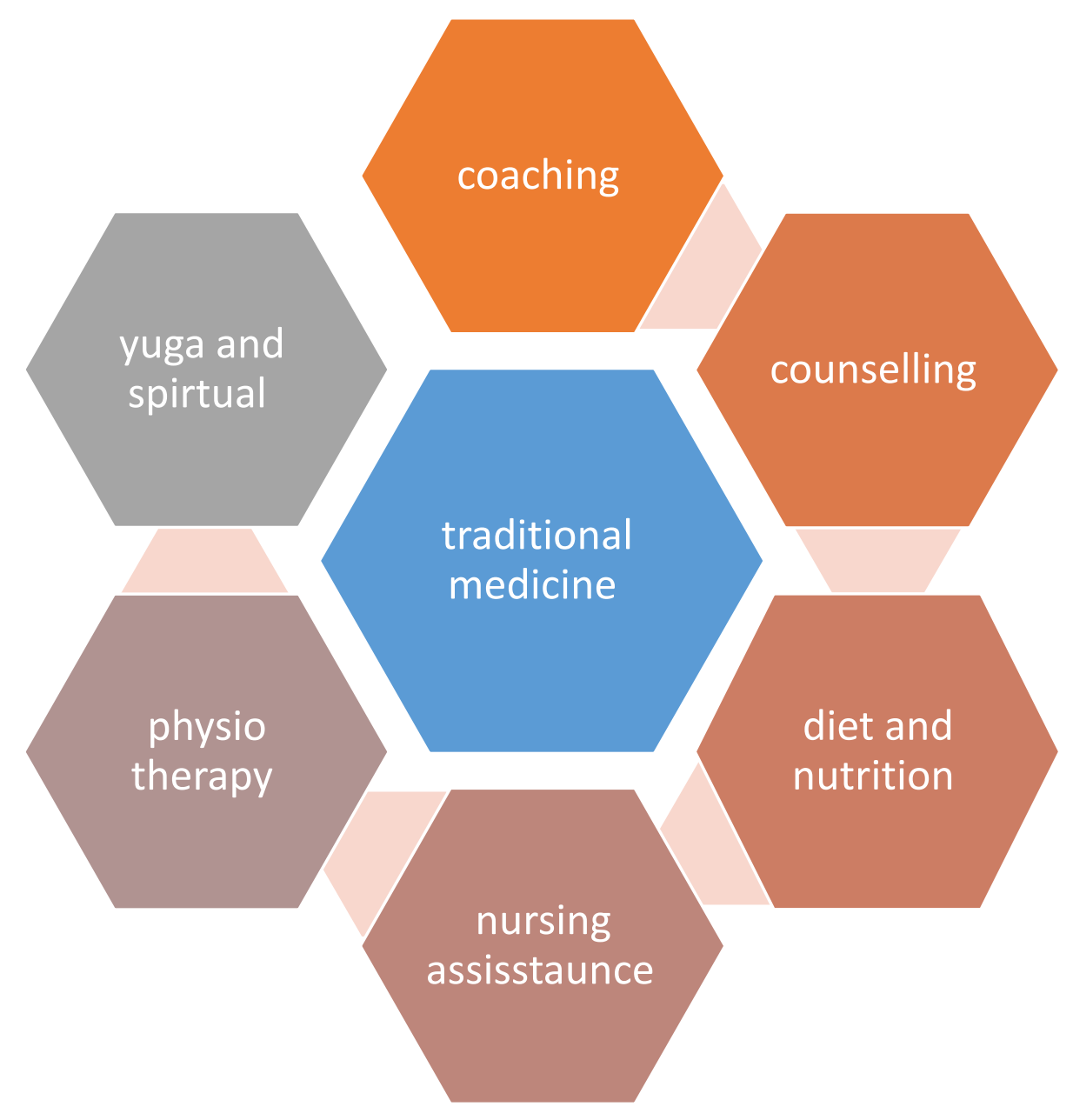

\section{Service Time for each customer}

The patient takes time in therapeutic nutrition clinic examination and in the Gymansium.

\section{Waiting Time to have the service}

The patient must take the proper time for a high quality service and to comply this mission we will make at least doctor for female patient and doctor for male patient.

The amount of the service produced Diet protocol, Gymnasium protocol and Nutrition Pharmacy. Ref. DIETARY SERVICES

\section{The supply chain design and management}

is a multi-disciplinary program designed to help us to create and implement innovative strategies that can help our organization serve customers effectively and efficiently.

Ref. supply chain - Jim Thulin 


\section{Benefits}

Value: adopt the value as a guiding principle to deliver superior managerial performance with significant business impact.

Alignment: Discover tools to align core process for operational excellence. Sustainability: understand frameworks to manage risks and opportunities for sustainable supply chain management on a global scale

\section{The Legal and Other Obligatory Studies}

- According to Egyptian laws and regulations

\section{Environmental study}

- Make plan for expected environmental risk

Ref. Egyptian guideline - Amro kandel .etc 2016

\section{PATIENT safety}

- Ensure patient safety to ensure high quality services and minimize risk Ref. DIETARY SERVICES

\section{Staff safety}

- Maintain the health and safety of health care workers

\section{Ref. HOSPITAL EVACUATION PLANNING GUIDE - Harvard - school of public health 2014}

\section{Social Study}

- Gain benefits of our nutrition unit

\section{Staff development}

- How to develop and improve the performance of employees

\section{Transportation of patient and staff}

\section{Capital budgeting}

- Construction of a new plant or a big investment in an outside venture are examples of projects that would require capital budgeting before they are approved or rejected.

- Methodology of fixed assets

- Methodology of expenses

- Methodology of cost reduction electricity

- Methodology of cost reduction water timed

- Methodology of maintenance of building and machines

- Methodology of cost of marketing of sales

- Methodology of method ways to increase and improve cash flow

- Methodology of method of feasibility study 


\section{Methods of long term contracts of buying of same resources}

\section{Methods of Crisis and Catastrophe management}

- Identification of Predicted Crisis and Catastrophe

- Make plan to meet them

- Predict the cost to cover them

Ref. Emergency Food Service: Planning for Disasters - Published by authority of the Minister of Health - Canada 2007

\section{$\underline{\text { Results }}$}

\section{The Marketing And Sales Planes}

The Customer Of The Nutrition clinic, Obesity And Thinness Management

Center was including most of the classes of the society with different entity :-
A. Healthy peoples
B. Patients
C. Organizations

\section{Healthy peoples}

- People searching for performing their health and increasing their physical fitness either males or females

- Atheletes

- Athletic clubs members and teams like football in El masry club and other social and athlete club in port-said

\section{Patients}

- Patient of acute and chronic diseases,

- Patient of renal failure

- Patients of diabetes mellitus and hypertension

- Patients of liver impairment

- Central line nutrition patient

- Patients of oncological diseases

- Malabsorption, general, weakness, cachexia, overweight (obesity)

- Patient of growth hormone disorders like retardation of the growth (pituitary) (thyroxin hormone imbalance)

- Cardiac patients e.g Ischemic Heart Disease (Coronary heart syndrome ) congestive heart failure (C.H.F) dyslipidemia

- Central nervous system disorder patients (neurological)

- Psycogenic poly-phagia (obesity)

- Anorexia nervosa

- Cachexia

- Paraplegia and hemiplegia

- Muscle disorder patients 
- Pediatric disorder e.g obesity, loss of appetite, parasitic, infestation, mal nutrition child, underweight, growth retardation.

Ref. Research and Segmentation - 2017 - Graystone Strategy Ltd.

Ref. Business-to-Consumer - WILL KENTON - Jul 11, 2020

\section{Organizations}

- The center can sale the experiences of its staff and nutrition protocol for other hospital and other healthy organization and increasing the benefits and profits of the therapeutic nutrition center

Super added value is the research unit in nutrition center for the scientific value on the nutrition researches at the level of global search.

Social Media advertising tools

Facebook, Instagram, you tube and Twitter.

Educational seminars for patients in all departments of hospital.

\section{Legal and Other Obligatory Studies}

According to Egyptian law number 51 for 1981

Ref. Legal study

\section{قانون رقم 51 لسنه 1981بتظيم المنشآت الطبية المعدل بالقانون 153 لسنة 2004}

\section{Environmental study}

Make plan for expected environmental risk

Hazards chemicals plan

- Implement a written program that meets the requirements of the Hazard Communication Standard to provide for worker training, warning labels, and access to Material Safety Data Sheets (MSDS).

Provide appropriate PPE: (e.g., gloves, goggles, splash aprons) when handling hazardous dishwashing detergents and chemicals

Medical Services and First Aid: Where the eyes or body of any person may be exposed to injurious corrosive materials, provide suitable facilities for quick drenching or flushing the eyes and body within the work area for immediate emergency use

- Use dishwashing machines that automate the dispensing of washing chemicals to minimize employee exposure to chemicals. Workers must still be cautious and use appropriate PPE (e.g., goggles, and/or gloves) when changing out the containers of detergent.

\section{Medical waste}

- Classification of medical waste to :

- Normal waste

- Medical waste: (human bodies-biological liquid-solid medical waste)

- Sharps

- Chemical waste 


\section{- Collection of each type:}

- Red bags for solid medical waste

- Black bags for normal waste

- Yellow bags for chemical waste

- Safe boxes for sharps

- Dedicated sewage for biological liquid

- Put standards for each material of collection bags and boxes

- Transport from department of the hospital to waste collection room safely at dedicated time and pass way and document the weight and type

- Transport waste to final disposal safely to incinerator and healthy burial according to laws and regulations of Egyptian environmental law

- Safe disposal of oily waste

Ref. Egyptian guideline - Amro kandel .etc 2016

\section{PATIENT safety}

- Follow patient safety roles and identification

- Identification of high alert medication

- Hand hygiene

- Improve effective communication

\section{Staff safety}

- Routine examination of workers and daily examination for any infectious diseases

- Health certificates for workers

\section{Social Study}

- Participate to reduce chronic disease and improve health

- Participate to increase productivity of population by improving their health

- Reduce mortality and morbidity

- Reduce mortality in premature babies by TPN solution

- Increase bed turnover rate

\section{Staff development}

- New employee orientation

- Department Specific Training

- Annual Continuing Education

- Annual Evaluation

\section{Ref. education programs - Pubmed.gov - 2018 May}

\section{Transport of patient and staff}

- Provide ambulance for patient

- Provide contract with Transportation Company for workers. 
Result of fixed assets

\begin{tabular}{|l|l|l|}
\hline STATMENT & PRICE & M \\
\hline Equipment & 187000 & 1 \\
\hline Computers & 12000 & 2 \\
\hline Furniture and décor & 24000 & 3 \\
\hline $\begin{array}{l}\text { Photocopier and fax and } \\
\text { print }\end{array}$ & 24000 & 4 \\
\hline Camera control & 23000 & 5 \\
\hline Fire extinguishers & 8000 & 6 \\
\hline Supplies and tools & 10200 & 7 \\
\hline Establishment expenses & 20000 & 8 \\
\hline Total & 308200 & \\
\hline
\end{tabular}

Ref. Finance \& Accounting - ADAM HAYES - Updated May 10, 2020

Ref. Finance \& Accounting - WILL KENTON - Updated Aug 19, 2020

Ref. Loan BasicsJULIA KAGAN - Apr 6, 2020

Temporary employment

\begin{tabular}{|l|l|l|l|l|l|}
\hline job & $\begin{array}{l}\text { Numbers } \\
\text { of } \\
\text { Employee }\end{array}$ & salaries & $\begin{array}{l}\text { Monthly } \\
\text { salaries }\end{array}$ & $\begin{array}{l}\text { annual } \\
\text { salaries }\end{array}$ \\
\hline$\underline{\mathbf{1}}$ & $\begin{array}{l}\text { Project } \\
\text { manager }\end{array}$ & $\mathbf{1}$ & $\mathbf{5 0 0 0}$ & $\mathbf{5 0 0 0}$ & $\mathbf{6 0 0 0 0}$ \\
\hline$\underline{\mathbf{2}}$ & accountant & $\mathbf{1}$ & $\mathbf{1 8 0 0}$ & $\mathbf{1 8 0 0}$ & $\mathbf{2 1 6 0 0}$ \\
$\underline{\mathbf{3}}$ & doctor & $\mathbf{1}$ & $\mathbf{5 0 0 0}$ & $\mathbf{5 0 0 0}$ & $\mathbf{6 0 0 0 0}$ \\
\hline$\underline{\mathbf{4}}$ & nurses & $\mathbf{2}$ & $\mathbf{2 0 0 0}$ & $\mathbf{4 0 0 0}$ & $\mathbf{4 8 0 0 0}$ \\
\hline$\underline{\mathbf{5}}$ & workers & $\mathbf{2}$ & $\mathbf{1 0 0 0}$ & $\mathbf{2 0 0 0}$ & $\mathbf{2 4 0 0 0}$ \\
\hline$\underline{\mathbf{6}}$ & trainer & $\mathbf{2}$ & $\mathbf{1 4 0 0}$ & $\mathbf{2 8 0 0}$ & $\mathbf{3 3 6 0 0}$ \\
\hline & & & & & $\underline{\mathbf{2 4 7 2 0 0}}$ \\
\hline
\end{tabular}


STATEMENT OF TOOLS AND MACHINES

\begin{tabular}{|l|l|l|l|l|l|}
\hline & Statement & Industry & numbers & price & total \\
\hline 1 & Steam room & Egyptian & 4 & 15000 & 60000 \\
\hline 2 & slimming devices & Egyptian & 2 & 12000 & 24000 \\
\hline 3 & Body massage bed & Egyptian & 15 & 2000 & 30000 \\
\hline 4 & Dedicated examination bed & Egyptian & 4 & 3500 & 14000 \\
\hline 5 & Sport tools and machines & Egyptian & 10 & 4900 & 49000 \\
\hline 6 & VARIOUS TOOLSA & Egyptian & 10 & 1000 & 10000 \\
\hline TOTAL & & & & 187000 \\
\hline
\end{tabular}

Other debit expenses

\begin{tabular}{|l|l|l|}
\hline & Statement & price \\
\hline 1 & Insurance & 55000 \\
\hline 2 & Rent in advance & 19200 \\
\hline 3 & Rent for 3 month & 61800 \\
\hline & Total & 136000 \\
\hline
\end{tabular}

\begin{tabular}{|c|c|c|}
\hline \multicolumn{3}{|l|}{ Investment expenses } \\
\hline Statement & Partial & total \\
\hline $\begin{array}{l}\text { Fixed capital } \\
\text { Machines } \\
\text { Computers } \\
\text { Furnitures and décor } \\
\text { Photocopier and fax } \\
\text { Camera control } \\
\text { Fire extinguishers } \\
\text { Supplies and tools } \\
\text { Establishment expenses } \\
\text { Total fixed capital }\end{array}$ & $\begin{array}{l}187000 \\
12000 \\
24000 \\
24000 \\
23000 \\
8000 \\
10200 \\
20000\end{array}$ & 30080 \\
\hline
\end{tabular}




\begin{tabular}{|l|l|l|}
\hline Secondly: & $\mathbf{7 4 8 0 0 0}$ & \\
The capital for 3 month & $\mathbf{6 1 8 0 0}$ & \\
Raw material 3 month & $\mathbf{8 3 8 0 0}$ & \\
Salary and wages for 3 month & $\mathbf{7 0 6 0 0}$ & \\
Other debt expenses & & \\
Cash & & \\
Total capital & & \\
Total investment cost & & \\
\hline & & \\
\hline
\end{tabular}


LIST OF CAPITAL FLOW

\begin{tabular}{|c|c|c|c|c|c|c|}
\hline Internal cash flow & $\frac{\text { Preparation }}{\text { period }}$ & $\underline{\text { First }}$ & second & THIRD & FOURTH & FIFTH \\
\hline SALES & & 2378456 & 3139562 & 4144222 & \begin{tabular}{|l|}
$\mathbf{5 3 8 7 4 4 8 8}$ \\
\end{tabular} & 7003735 \\
\hline \multicolumn{7}{|l|}{$\begin{array}{l}\text { EXTERNAL CACH } \\
\text { FLOW }\end{array}$} \\
\hline INVESTMENT COST & 1272400 & $\mathbf{0}$ & $\mathbf{0}$ & $\mathbf{0}$ & $\mathbf{0}$ & $\mathbf{0}$ \\
\hline SALES COST & $\mathbf{0}$ & 1450112 & 1885146 & 1998254 & 2118150 & 2245239 \\
\hline $\begin{array}{l}\text { ADMINSTRATIVE } \\
\text { EXPENSES }\end{array}$ & $\mathbf{0}$ & 92700 & 94554 & 99282 & 104246 & 109458 \\
\hline $\begin{array}{l}\text { REPAYMENT THE } \\
\text { LOANS AND THE } \\
\text { INTEREST }\end{array}$ & & 200000 & 200000 & 200000 & 200000 & 200000 \\
\hline $\begin{array}{l}\text { REPAYMENT AND } \\
\text { INTEREST }\end{array}$ & $\mathbf{0}$ & 50000 & 40000 & 30000 & 20000 & 10000 \\
\hline EXTERNAL FLOW & & 1792812 & 2219700 & 2327536 & 2442395 & 2564697 \\
\hline |THE NET & 1272400- & 686756- & 233106 & 2049792 & 4994885 & 9433923 \\
\hline THE TAXES & & $\mathbf{0}$ & $\mathbf{0}$ & 461203 & 1123849 & 2122633 \\
\hline $\begin{array}{l}\text { THE NET PROFIT } \\
\text { AFTER TAXES }\end{array}$ & & $686756-$ & 233106 & 1588589 & 3871036 & 7311290 \\
\hline
\end{tabular}

Ref. Fundamental Analysis - SEAN ROSS - Updated Aug 7, 2019

Ref. Capital Budgeting - WILL KENTON - Updated Aug 19, 2020

Ref. A cost management - Liliana Neriz - November 2014

\section{Conclusion}

From our work we concluded the importance of our nutrition unit

- Participate to reduce chronic disease and improve health.

- Participate to increase productivity of population by improving their health.

- Reduce mortality and morbidity and increase productivity in community.

- Reduce mortality in premature babies by TPN solution.

- Increase bed turnover rate.

We are in high need to this clinic in port said city 


\section{$\underline{\text { Recommendation }}$}

Providing therapeutic nutrition clinic TNC that will promote health in all members our society not only the diseased ones but also the healthy ones.

It will help them improve quality of life this will decrease morbidity $\&$ mentality rates.

This will increase persons productivity in our community.

\begin{tabular}{|c|c|c|}
\hline \multicolumn{3}{|r|}{ Reference } \\
\hline job description & $\begin{array}{l}\text { JAMES PHELAN } \\
\text { MARCH 22, } 2018\end{array}$ & $\begin{array}{l}\text { https://cpl.com/cpl-insights/insight-recruit/4- } \\
\text { differences-between-a-job-description-and-a-job- } \\
\text { specification/ }\end{array}$ \\
\hline $\begin{array}{l}\text { Monitoring } \\
\text { techniques }\end{array}$ & & $\begin{array}{l}\text { https://www.dlsweb.rmit.edu.au/Toolbox/busadmi } \\
\text { n/topics/topic41/t41_03.htm }\end{array}$ \\
\hline Supply Chain & Jim Thulin & $\begin{array}{l}\text { https://optilon.com/what-do-we-offer/supply-chai- } \\
\text { n-design/ }\end{array}$ \\
\hline marketing & Michael Richter & $\begin{array}{l}\text { http://www.marketing-und-vertrieb- } \\
\text { international.com/en/marketing-and-sales/sales- } \\
\text { planning-sales-concept.htm }\end{array}$ \\
\hline $\begin{array}{l}\text { sales and } \\
\text { marketing }\end{array}$ & $\begin{array}{l}\text { O2014 Australian } \\
\text { Business Consulting } \\
\text { \& Solutions } \\
\end{array}$ & $\begin{array}{l}\text { http://www.australianbusiness.com.au/marketing/ } \\
\text { marketing-strategy/sales-marketing-strategy }\end{array}$ \\
\hline \begin{tabular}{|l|} 
Market \\
Segmentation
\end{tabular} & $\begin{array}{l}\text { JENNIFER } \\
\text { YESBECK } \\
\end{array}$ & $\begin{array}{l}\text { https://blog.alexa.com/types-of-market- } \\
\text { segmentation/ }\end{array}$ \\
\hline $\begin{array}{l}\text { Research and } \\
\text { Segmentation }\end{array}$ & \begin{tabular}{|l|}
2017 - Graystone \\
Strategy Ltd.
\end{tabular} & $\begin{array}{l}\text { https://www.graystonestrategy.com/services/resea } \\
\text { rch-and-analysis/research-and-segmentation/ }\end{array}$ \\
\hline $\begin{array}{l}\text { Demand } \\
\text { Theory }\end{array}$ & $\begin{array}{l}\text { ADAM HAYES } \\
\text { Updated Jul 8, } 2019\end{array}$ & $\begin{array}{l}\text { https://www.investopedia.com/terms/d/demand_t } \\
\text { heory.asp\#: :text=Demand\%20is\% 20simply\%20 } \\
\text { the\% 20quantity,\%2C\%20entertainment \%2C\%2 } \\
\text { 0shelter\%2C\%20etc. }\end{array}$ \\
\hline $\begin{array}{l}\text { Marketing } \\
\text { Strategy }\end{array}$ & \begin{tabular}{|l|} 
By ADAM \\
BARONE \\
Reviewed By \\
MARGARET \\
JAMES \\
Updated Apr 29, \\
2020 \\
\end{tabular} & $\begin{array}{l}\text { https://www.investopedia.com/terms/m/marketing } \\
\text { - } \\
\text { strategy.asp\#: :text=A\%20marketing\% 20strateg } \\
\text { y\%20refers\% \%0to,or\% 20services\% 20the\% 20bus } \\
\text { iness\% 20provides. }\end{array}$ \\
\hline
\end{tabular}




\begin{tabular}{|c|c|c|}
\hline $\begin{array}{l}\text { Types of } \\
\text { Marketing } \\
\text { Strategies } \\
\end{array}$ & Feb 20, 2014 & $\begin{array}{l}\text { https://www.slideshare.net/cultbranding.com/52- } \\
\text { types-of-marketing-strategies-31453870 }\end{array}$ \\
\hline $\begin{array}{l}\text { The Sales } \\
\text { Strategy }\end{array}$ & $\frac{\text { Dave }}{\frac{\text { Egloff }}{2019}} \mid$ March 12, & $\begin{array}{l}\text { https://blogs.gartner.com/dave- } \\
\text { egloff/2019/03/12/sales-strategy-design-journey/ }\end{array}$ \\
\hline $\begin{array}{l}\text { Fundamental } \\
\underline{\text { Analysis }}\end{array}$ & $\frac{\text { SEAN ROSS }}{\text { Updated Aug 7, }}$ & $\begin{array}{l}\text { https://www.investopedia.com/ask/answers/11261 } \\
\text { 4/whats-difference-between-cost-goods-sold-cogs- } \\
\text { and-cost-sales.asp }\end{array}$ \\
\hline Legal study & 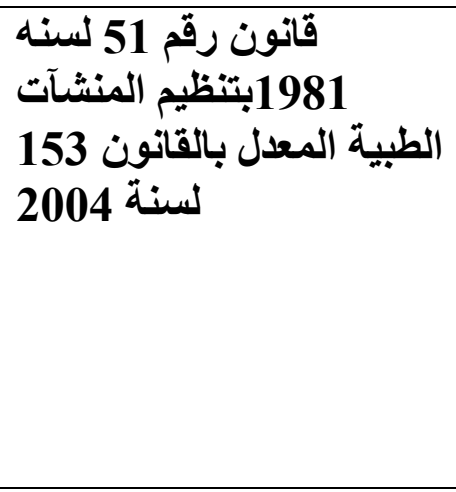 & $\begin{array}{l}\text { https://egylawsite.wordpress.com/2016/02/11/\%D9\%82\% } \\
\text { D8\%A7\%D9\%86\%D9\%88\%D9\%86- } \\
\text { \%D8\%B1\%D9\%82\%D9\%85-51- } \\
\text { \%D9\%84\%D8\% B3\%D9\%86\%D9\%87- } \\
\text { 1981\%D8\% A8\%D8\%AA\%D9\%86\%D8\%B8\%D9\%8A } \\
\text { \%D9\%85- } \\
\text { \%D8\%A7\%D9\%84\%D9\%85\%D9\%86\%D8\%B4\%D8\% } \\
\text { A2\%D8\%AA- } \\
\text { \%D8\%A7\%D9\%84\%D8\%B7\%D8\%A8\%D9\%8A\%D8 } \\
\text { \%A9/ }\end{array}$ \\
\hline $\begin{array}{l}\text { education } \\
\text { programs }\end{array}$ & $\begin{array}{l}\text { Pubmed.gov - } 2018 \\
\text { May }\end{array}$ & https://pubmed.ncbi.nlm.nih.gov/29362024/ \\
\hline $\begin{array}{l}\text { HOSPITAL } \\
\text { EVACUATIO } \\
\text { N PLANNING } \\
\text { GUIDE }\end{array}$ & $\begin{array}{l}\text { Harvard - school of } \\
\text { public health } 2014\end{array}$ & $\begin{array}{l}\text { https://www.mass.gov/doc/evacuation-toolkit- } \\
\text { planning-guide-0/download }\end{array}$ \\
\hline $\begin{array}{l}\text { Egyptian } \\
\text { guideline }\end{array}$ & Amro kandel .etc & $\begin{array}{l}\text { https://apps.who.int/iris/bitstream/handle/10665/1 } \\
\text { 19757/dsa452.pdf? }\end{array}$ \\
\hline $\begin{array}{l}\text { DIETARY } \\
\text { SERVICES }\end{array}$ & & $\begin{array}{l}\text { http://www.hpm.umn.edu/nhregsplus/NHRegs_by } \\
\text { State/Maine/maine_chapter_18_dietary_services } \\
\text {.pdf }\end{array}$ \\
\hline $\begin{array}{l}\text { Capital } \\
\text { Budgeting }\end{array}$ & $\begin{array}{l}\frac{\text { WILL KENTON }}{\text { Updated Aug 19, }} \\
2020\end{array}$ & $\begin{array}{l}\text { https://www.investopedia.com/terms/c/capitalbud } \\
\text { geting.asp\#: :text=Capital\% 20budgeting\% } \% \text { 20is\% } \\
\text { 20the\% } 20 \text { process,they \% 20are\% } \% \text { approved \% } 20 \\
\text { or\%20rejected. }\end{array}$ \\
\hline $\begin{array}{l}\text { Finance \& } \\
\text { Accounting }\end{array}$ & $\begin{array}{l}\text { ADAM HAYES - } \\
\text { Updated May 10, } \\
2020\end{array}$ & $\begin{array}{l}\text { https://www.investopedia.com/terms/c/currentass } \\
\text { ets.asp\#: :text=Current \% 20assets\% 20represent } \\
\% 20 \text { all\% 20the,must \% 20be \% 20completed \% 20ea } \\
\text { ch\%20year. }\end{array}$ \\
\hline $\begin{array}{l}\text { Finance \& } \\
\text { Accounting }\end{array}$ & $\begin{array}{l}\text { WILL KENTON - } \\
\text { Updated Aug 19, } \\
2020\end{array}$ & $\begin{array}{l}\text { https://www.investopedia.com/terms/c/currentrati } \\
\text { o.asp\#: :text=The\%20current\%20ratio\%20is\%2 } \\
\text { 0a,current\%20debt\%20and\%20other\%20payabl } \\
\underline{\text { es }}\end{array}$ \\
\hline
\end{tabular}




\begin{tabular}{|c|c|c|}
\hline Loan Basics & $\frac{\text { JULIA KAGAN - }}{\text { Apr 6, 2020 }}$ & $\begin{array}{l}\text { https://www.investopedia.com/terms/e/equated_m } \\
\text { onthly_installment.asp\#: :text=An\% 20equated\% } \\
\text { 20monthly\% 20installment\% 20(EMI)\% 20is\% \%a } \\
\text { \% 20fixed\%20payment\% 20amount,is\% 20paid\% } \\
\text { 20off\%20in\%20full }\end{array}$ \\
\hline $\begin{array}{l}\text { Business-to- } \\
\text { Consumer }\end{array}$ & $\frac{\text { WILL KENTON - }}{\text { Jul 11, 2020 }}$ & $\begin{array}{l}\text { https://www.investopedia.com/terms/b/btoc.asp\#: } \\
\text { :text=The\% 20term\%20business\% 2Dto\% 2Dcon } \\
\text { sumer,referred\% 20to\% 20as\%20B2C\% 20compa } \\
\text { nies }\end{array}$ \\
\hline $\begin{array}{l}\text { Feasibility } \\
\text { Study }\end{array}$ & $\begin{array}{l}\text { By SimplilearnLast } \\
\text { updated on Aug 20, } \\
2020\end{array}$ & $\begin{array}{l}\text { https://www.simplilearn.com/feasibility-study- } \\
\text { article }\end{array}$ \\
\hline $\begin{array}{l}\text { Feasibility } \\
\text { Study }\end{array}$ & $\frac{\text { Kathy, March 27, }}{\underline{2019}}$ & $\begin{array}{l}\text { https://www.projectcubicle.com/feasibility-study- } \\
\text { in-project-management/ }\end{array}$ \\
\hline $\begin{array}{l}\text { Emergency } \\
\text { Food Service: } \\
\text { Planning for } \\
\text { Disasters }\end{array}$ & $\begin{array}{l}\text { Published by } \\
\text { authority of the } \\
\text { Minister of Health - } \\
\text { Canada } 2007 \\
\end{array}$ & $\begin{array}{l}\text { https://www.interiorhealth.ca/YourEnvironment/ } \\
\text { Emergency/MajorEvents/Documents/Emergency- } \\
\text { Food-Services-Planning-for-Disasters.pdf }\end{array}$ \\
\hline $\begin{array}{l}\text { A cost } \\
\text { management }\end{array}$ & $\begin{array}{l}\text { - } \frac{\text { Liliana Neriz - }}{\text { November }} \\
2014\end{array}$ & $\begin{array}{l}\text { https://www.researchgate.net/publication/2682278 } \\
\text { 52_A_cost_management_model_for_hospital_foo } \\
\text { d_and_nutrition_in_a_public_hospital }\end{array}$ \\
\hline
\end{tabular}

